\title{
Cytometric DNA analysis and prognostic biomarkers in breast carcinoma. Expression of P53 product in the different ploidy classes*
}

\author{
Elena Leonardi ${ }^{\mathrm{a}, * *}$, Antonella Cristofori ${ }^{\mathrm{a}}$, Orazio $\mathrm{Caffo}^{\mathrm{b}}$ and Paolo Dalla Palma ${ }^{\mathrm{a}}$ \\ ${ }^{\mathrm{a}}$ Department of Anatomic Pathology and ${ }^{\mathrm{b}}$ Department of Oncology, S. Chiara Hospital, Trento, Italy
}

Received 7 February 1997

Revised 26 May 1997

\begin{abstract}
The aim of the study was to correlate the DNA Index (DI) and S-phase fraction (SPF) values determined by multiparametric flow cytometry in breast cancer (mainly T1 and T2 stages) with several clinico-pathologic variables and other biological parameters. For this purpose, a total of 136 breast cancers were submitted to flow cytometry and to several types of immunohistochemical analyses. Among clinico-pathologic data we considered $\mathrm{pT}, \mathrm{pN}$ and grade and among immunohistochemical markers, hormonal receptors, P53, c-erbB-2 and MIB-1. We found that DNA aneuploidy was strongly correlated with high tumoral grade, absence of hormonal receptors, high proliferation, as shown by high MIB-1 $(\geqslant 36 \%)$ and SPF values $(\geqslant 13.3 \%)$, and P53 positivity. Grouping the tumours according to their DI values, we observed a relative significantly higher correlation of the near-triploid range carcinomas (DI 1.40-1.60) with immunohistochemical expression of P53 $(p=0.0001)$. Near-triploid DI was also associated with a high proliferative activity, expressed both by $\operatorname{SPF}(p=0.0001)$ and MIB-1 reactivity $(p=0.0001)$, high tumoral grade $(p=0.0001)$ and presence of axillary metastases $(p=0.03)$. These data suggest that DNA near-triploid tumours in breast cancer may have a more aggressive behaviour in comparison with other DI classes.
\end{abstract}

Keywords: Ploidy, breast cancer, P53, prognostic markers

\section{Introduction}

The clinical course of breast carcinoma is partially unpredictable despite enhanced improvements in diagnoses and therapies. The outcome of neoplastic disease in terms of local recurrence, distant metastases and progression was and is upto now the major goal of several studies aimed at identifying reliable prognostic factors.

At present, prognosis is based on clinico-pathological parameters such as tumour size, nodal status, histological type and nuclear grade. However, these parameters are influenced by the subjectivity of

\footnotetext{
${ }^{*}$ This research was presented at the XVIIIth ISAC Congress, 13-18 April 1996, Rimini, Italy.

${ }^{* *}$ Corresponding author. Address: Leonardi Elena, Anatomia Patologica, Ospedale S. Chiara, via Crosina Sartori 6, Trento, 38100, Italy. Tel.: +39 461 903303; fax: +39 461 903389; email: pdpalma@cmbm.itc.it.
} 
the pathologist and, therefore, limited in their predictive value [42]. It is therefore necessary to couple the traditional morphological parameters, to a deeper understanding of the biological nature of the neoplastic disease in order to select a subgroup of high risk patients for developing new therapeutic protocols.

Several papers indicate that the most significant biological markers in breast cancer are immunohistochemical detection of steroid receptors, proliferating cell nuclear antigen MIB-1, c-erbB-2, P53.

The presence of estrogen and progesteron receptor proteins in neoplastic cells is well established as a predictor of clinical response to endocrine therapy and it is as well related to a better ultrastructural, nuclear and histological differentiation [12,13,26,40]. MIB-1 is an important factor related to the proliferative rate of the tumour. Several papers have shown the prognostic value of the immunohistochemical expression of MIB-1 in breast cancer [2,11,15,21]. Neoplastic transformation related proteins such as the product of oncogene overexpression c-erbB-2 and the product of mutant oncosuppressor gene P53 seem to be involved in conferring a more aggressive biological behaviour to the tumour $[1,17,24,31,35,36,38,45]$. Analytical cytology techniques, and particularly flow cytometry for determination of DNA content abnormality and S-phase fraction represent rapid, automated and sensitive tools to identify important characteristics predictive of tumour outcome [10]. These flow cytometric variables have been previously discussed in several studies, but their predictive value is conflicting $[3,14,18,28]$.

Disagreement between different studies has been previously discussed, indicating in heterogeneity among patients' stage, type of material (paraffin vs. fresh), tissue processing procedures, admixture of non-tumour cells and differences in cell cycle analysis methodology some of the possible explanations $[4,7,18]$.

The present prospective study is characterized by uniformity in the study population (mainly $\mathrm{T} 1$ and $\mathrm{T} 2$ stages) and in the material used (fresh tissue only).

The purpose of our study was to correlate flow cytometric data, including DNA indices and S-phase fraction values, determined by multiparametric procedures, to several clinico-pathologic variables and biological parameters. As a result of these analyses we have identified a DNA-phenotype characterized by DNA near-triploid content ( $\mathrm{DI}=1.5 \pm 0.1$ ) that appears to have a more aggressive biological behaviour.

\section{Materials and methods}

The study population consisted of 136 patients with histologically proven breast cancer, collected prospectively in the Pathology Department at S. Chiara Hospital (Trento, Italy) between 1994 and 1996. They represented diagnostic samples of biopsies received fresh for pathologic evaluation.

\subsection{Histopathologic evaluation}

Breast cancer biopsies were diagnosed by a pathologist (P.D.P.), according to the WHO classification and histopathologically graded following the Bloom and Richardson system [8]. Tumour stages were assigned according to the TNM classification [37].

Clinical characteristics of the study population are summarized in Table 1. 
Table 1

Clinico-pathologic characteristics of the study population ${ }^{\mathrm{a}}$

\begin{tabular}{lc}
\hline Total number of patients & 136 \\
Clinico-pathologic stage & \\
T1 & $79(58 \%)$ \\
T2 & $50(37 \%)$ \\
T3 & $2(1 \%)$ \\
T4 & $5(4 \%)$ \\
Grading & \\
G1 & $25(19 \%)$ \\
G2 & $56(41 \%)$ \\
G3 & $55(40 \%)$ \\
Nodal status & \\
N0 & $69(51 \%)$ \\
N+ & $67(49 \%)$ \\
\hline
\end{tabular}

${ }^{\text {a }}$ Stage was assigned according to the TNM classification; grading was assigned according to Bloom and Richardson; $\mathrm{N} 0$, absence of axillary metastases; $\mathrm{N}+$, presence of axillary metastases.

\subsection{Immunohistochemistry}

Routinely processed, formalin fixed, paraffin embedded tissues were cut into sections $5 \mu \mathrm{m}$ thick. Antigen retrieval was performed using an $800 \mathrm{~W}$ microwave oven at full power in citrate buffer $\mathrm{pH} 6.0$ for two cycles $10 \mathrm{~min}$ each [34]. Slides were incubated at $4{ }^{\circ} \mathrm{C}$ for $2 \mathrm{~h}$ with the following antibodies: estrogen receptor (clone 1D5, DAKO, Glostrup, Denmark) dilution $1: 150$, progesteron receptor (clone 1A6, DAKO, Glostrup, Denmark) dilution 1:100 and MIB-1 (clone MIB-1, IMMUNOTECH S.A., Marseille Cedex, France) dilution $1: 150$.

P53 (clone DO7, DBA, Milano, Italy) dilution $1: 1000$ [5] and c-erbB-2 (clone CB11, NOVOCASTRA, Newcastle upon Tine, UK) dilution $1: 200$ were applied overnight at $4{ }^{\circ} \mathrm{C}$.

Biotinylated anti mouse $\operatorname{IgG}$ and streptavidin-biotin enhanced immunoperoxidase technique (StrepABcomplex/HRP, duet, mouse/rabbit, DAKO, Glostrup, Denmark) were applied in sequence. The immunostaining for estrogen and progesteron receptors was assessed by one observer (EL) on the basis of the visually estimated percentage of neoplastic cells with positive nuclear staining and on staining intensity. On the basis of the percentage of stained cells, the lesions were subdivided in four classes, i.e.: $>10 \% ; 10-25 \% ; 25-50 \%$; $>50 \%$. Staining intensity was graded as low $(+)$, moderate $(++)$ and intense $(+++)$. All cases with negative staining and those with less than $10 \%$ stained cells were regarded as negative, and for the purpose of statistical analysis, all cases with more than $10 \%$ stained cells, independent of intensity, were regarded as positive. MIB-1 immunoreactivity was scored counting at least 500 cells in more than 10 high power $(1000 \times)$ representative fields. In cases where intratumoral heterogeneity of staining was seen, the fields included those with the highest and the lowest percentage of stained cells. Percentile expression of MIB-1 in neoplastic cells was divided in tertiles: low $(\leqslant 20 \%)$, medium $(21-35 \%)$, high $(\geqslant 36 \%)$.

Quantification of nuclear P53 immunostaining was estimated analysing 10 consecutive $1000 \times$ microscopic fields $(100 \times$ objective and $10 \times$ oculars) containing malignant cells (Fig. 1). All cases with negative staining and those with less than $10 \%$ stained cells were regarded as negative, while cases with more than $10 \%$ stained cells, independent of intensity, were regarded as positive. C-erbB-2 


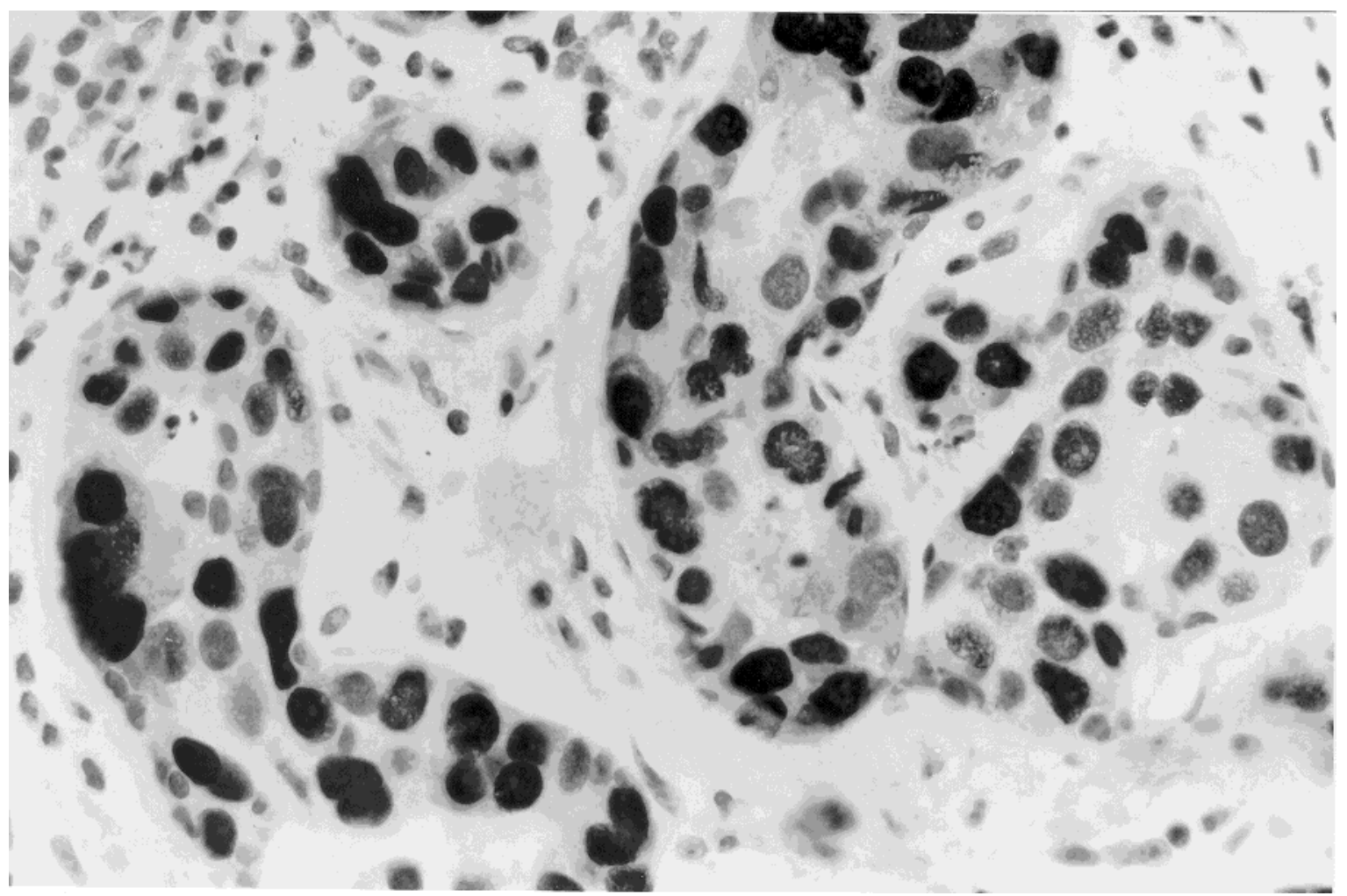

Fig. 1. Poorly differentiated adenocarcinoma of the breast showing strong nuclear immunoreactivity for P53 in most of the neoplastic cells (original magnification $\times 400$ ).

overexpression was identified as positive only in cases exhibiting distinct membrane staining in all or a majority of tumour cells (Fig. 2) [5]. Cases with only focal membrane staining and with distinct cytoplasmic staining were considered negative.

\subsection{Flow cytometry}

Our methodological approach included two different procedures: a) monoparametric analysis for quantification of DNA content; and b) biparametric analysis which couples the DNA measurement to the detection of a cytoplasmic antigen for the identification of epithelial cells. This method, widely documented in previous reports $[22,41,43,46-50]$ allows to refine biologic relevance of flow cytometric data. Biparametric analysis optimizes the definition of the DNA diploid peak, sensitivity in the identification of aneuploid tumour cell population and assessment of S-phase fraction.

All cases were submitted to both monoparametric and biparametric procedures.

\section{a) Sample preparation}

Surgical specimens were cut into pieces of $0.3-0.5 \mathrm{~cm}^{3}$ and immediately frozen at $-80^{\circ} \mathrm{C}$. At the time of analysis, specimens were treated with a procedure for flow cytometric analysis which optimizes the discrimination of stemlines, achieving low CV values (medium CV: 2.4; range: 1.3-3.5; Fig. 3). Samples were thawed rapidly at $37{ }^{\circ} \mathrm{C}$, released from necrotic, haemorragic and fat areas 


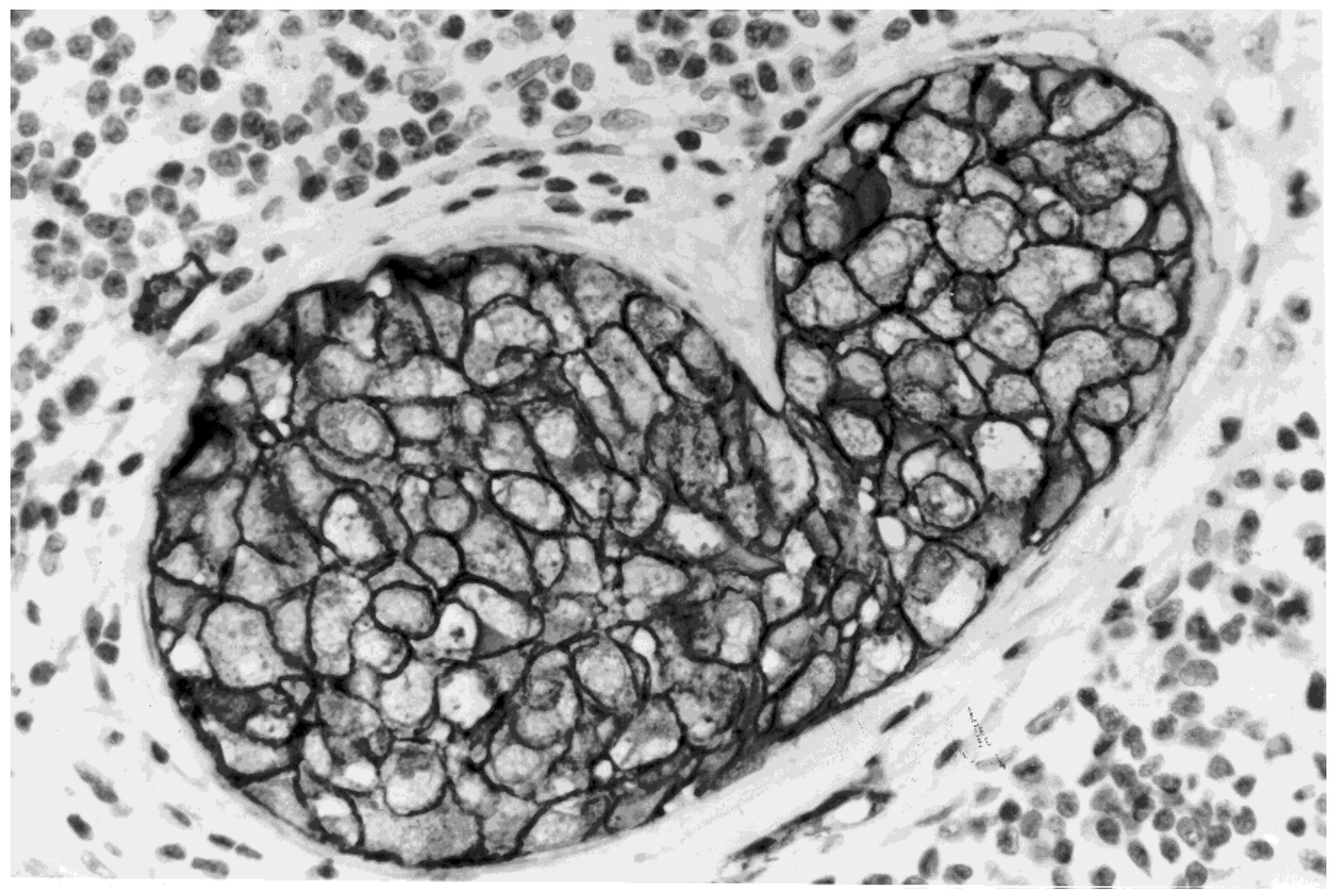

Fig. 2. Immunoreactivity for c-erbB-2 in a ductal invasive carcinoma of the breast. It is evident a cell membrane staining pattern (original magnification $\times 400$ ).

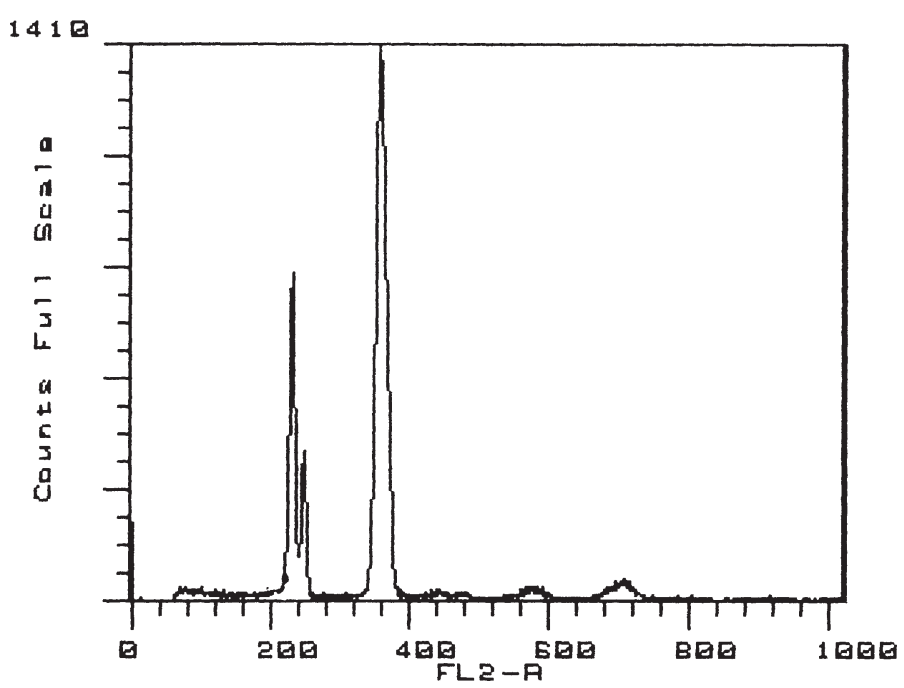

Fig. 3. Detection of a DNA near-diploid peak with DI $=1.07$ and a DNA near-triploid peak with DI $=1.56$. CV of G0-G1 DNA diploid peak (left) was $1.91 \%$. 
and disaggregated mechanically for $30 \mathrm{sec}$ (Medimachine, ConsulTS, Rivalta di Torino, Italy) in PBS pH 7.4 (Phosphate Buffered Saline Tablets, P-4417, SIGMA, St. Louis, MO, USA). Cell suspensions were filtered through a $50 \mu \mathrm{m}$ nylon mesh and placed for $15 \mathrm{~min}$ at $4{ }^{\circ} \mathrm{C}$ (sedimentation step). Supernatants were successively centrifuged at $600 \mathrm{rpm}$, low power, for $10 \mathrm{~min}$, and washed twice in PBS. Pellets were incubated for $2 \mathrm{~h}$ at $4^{\circ} \mathrm{C}$ in $1 \mathrm{ml}$ PBS containing propidium iodide $(50 \mu \mathrm{g} / \mathrm{ml}$, P-4170, SIGMA, St. Louis, MO, USA), RNase ( $1 \mathrm{mg} / \mathrm{ml}$, R-4875, SIGMA, St. Louis, MO, USA) and Nonidet P-40 $(0.25 \mu \mathrm{l} / \mathrm{ml}, \mathrm{N}-6507$, SIGMA, St. Louis, MO, USA) [25]. In order to evaluate the quality control of cytometric procedures an aliquot of cell suspension analysed by flow cytometry was smeared and microscopically examined.

\section{b) Sample preparation for biparametric analysis}

Fresh surgical specimens were mechanically disaggregated with the above procedure. Pellets were stored at $-80^{\circ} \mathrm{C}$ in a propylen tube containing a cryopreservative solution composed of fetal bovine serum (cat. $\mathrm{n}^{\circ}$ F-3018, SIGMA, St. Louis, MO, USA) $10 \%$ and dimethylsulfoxide (cat. ${ }^{\circ}$ D-5879, SIGMA, St. Louis, MO, USA) 10\% in RPMI 1640 Medium (R-8758, SIGMA, St. Louis, MO, USA). At the time of analysis, tubes were rapidly thawed at $37^{\circ} \mathrm{C}$ and divided into two separate aliquots. Cell suspensions were centrifuged at $600 \mathrm{rpm}$ for $10 \mathrm{~min}$ at low power. Pellets were fixed with cold $70 \%$ ethanol for $30 \mathrm{~min}$. After centrifugation pellets were washed twice in a solution composed by 5\% FBS, 0.1\% Albumin Bovine (cat. $\mathrm{n}^{\circ}$ A-2153, SIGMA, St. Louis, MO, USA) in PBS.

Finally, the pellet of the first aliquot was incubated $1 \mathrm{~h}$ at $4{ }^{\circ} \mathrm{C}$ with a monoclonal antibody against cytokeratin 8/18 (CAM 5.2/FITC, cat. $\mathrm{n}^{\circ}$ 34765, Becton Dickinson Immunocytometry Systems, San Jose, CA, USA) diluted 1:20 in $250 \mu \mathrm{l}$ of 50 gamma PI solution containing $0.1 \%$ RNase and $0.25 \%$ NP-40. Pellet for the negative control was incubated for $1 \mathrm{~h}$ at $4{ }^{\circ} \mathrm{C}$ with a non-specific isotypic mouse IgG1 (MOPC-21FITC conjugate, cat. $\mathrm{n}^{\circ} \mathrm{F}-6397$, SIGMA) under the same experimental conditions as the test sample. At the end of the incubation time, cell suspensions were washed in $1 \mathrm{ml}$ of PI/RNase solution [49] that had been added to each tube and mixed.

Tubes were immediately centrifuged at $600 \mathrm{rpm}$ for $10 \mathrm{~min}$. Cell pellets were resuspended in $500 \mu \mathrm{l}$ of PI solution and analysed after $2 \mathrm{~h}$. In order to evaluate the presence of cytokeratin-positive cells, an aliquot of cell suspension was smeared and examined by fluorescent microscope (Fig. 4).

\section{c) FCM analysis}

FCM analysis was performed on a FACScan flow cytometer (Becton Dickinson Immunocytometry Systems, Mountain View, CA, USA), equipped with a $15 \mathrm{~mW}$ argon laser $(488 \mathrm{~nm})$ and doublet discrimination module. A Cell FIT Software Package was used for instrument set-up, data acquisition and histogram deconvolution. Instrument set-up and calibration were performed using a propidium iodide stained diploid normal tissue. At least 20,000 events were recorded for each sample in list mode data using 1024 channels.

\section{d) Gating method}

Populations with positive staining for cytokeratin were identified by comparing FL3-H and FL1-H dot plots of the tested sample with the negative control. Samples were considered adequately labelled only when a distinct visual separation in green fluorescence intensity (FL1-H histogram) was present (Fig. 5). 


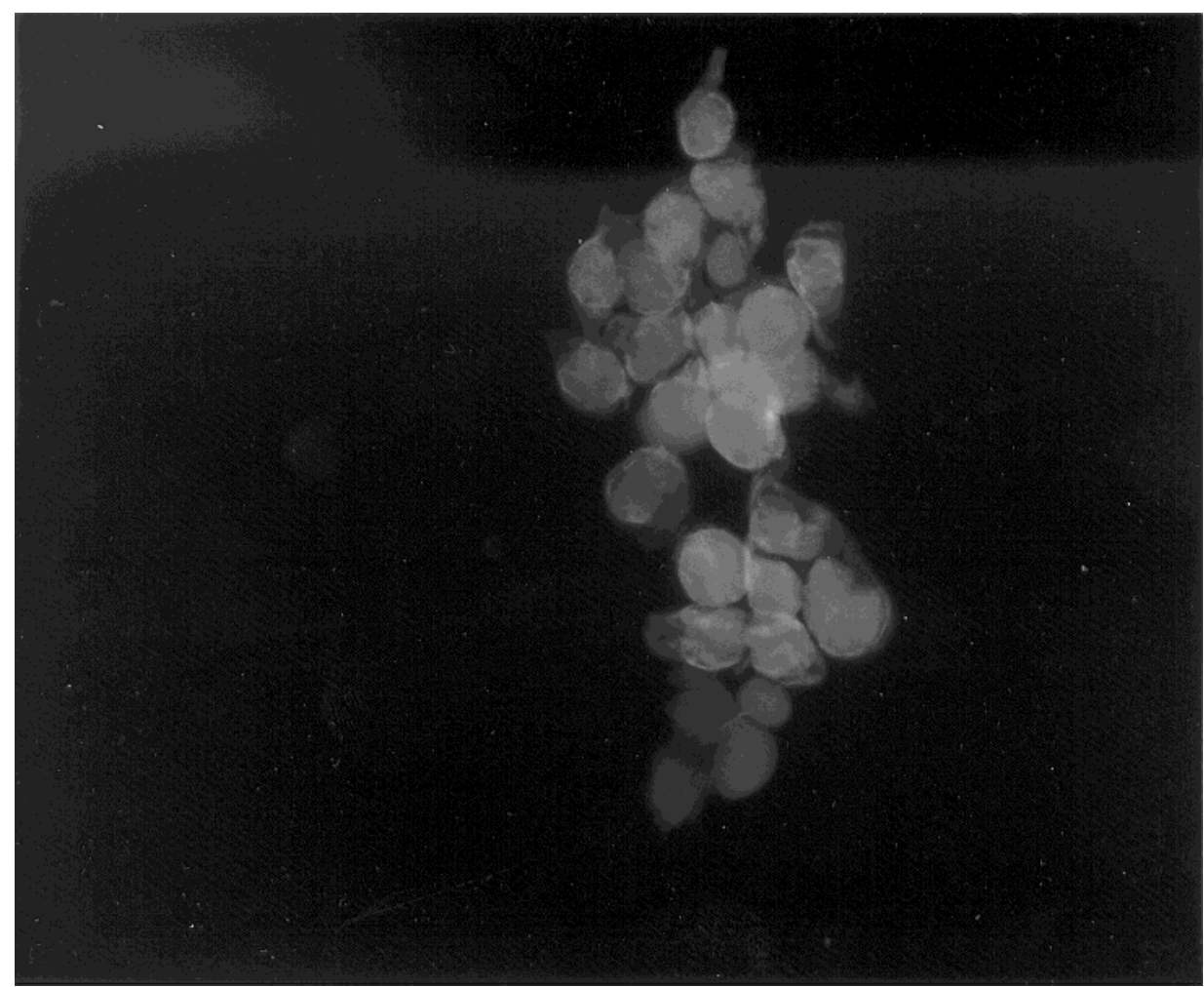

Fig. 4. Suspension of intact cells obtained from a breast carcinoma by mechanical disaggregation. Cells were labelled with an antibody to cytokeratin 8 and 18 (CAM5.2-FITC, green fluorescence in the cytoplasm) and Propidium Iodide (red fluorescence in the nucleus) (original magnification $\times 400$ ).

\section{e) Histogram interpretation}

Cell cycle analysis was calculated by rectangular curve fitting (RFIT, Becton Dickinson, CellFIT Software) for diploid tumour and by polynomial model (POLY Model) when the sample contained two cell populations with different DNA contents. Histograms including a single G0/G1 peak were considered DNA diploid (DI $=1.00)$. When more than one $\mathrm{G} 0 / \mathrm{G} 1$ peak was present, histograms were classified as follows: DNA hypodiploid (DI $<1.00)$, DNA near-diploid $(1.00<$ DI $<1.39$ ), DNA near-triploid $(1.40<$ DI $<1.60)$, DNA hypertriploid $(1.61<$ DI $<1.79)$, DNA near-tetraploid $(1.80$ $<$ DI $\leqslant 2.10$ ), DNA hypertetraploid (DI $>2.10$ ), DNA multiploid when more than one aneuploid population was found [44]. Tumours were classified as tetraploid only when a corresponding G2/M peak was identifiable. Histograms were considered reliable when the C.V. of the G0/G1 diploid peak was lower than $3.5 \%$. SPF values obtained by biparametric procedure were divided in tertiles: low $(\leqslant 5.5 \%)$, medium $(5.6-13.2)$, high $(\geqslant 13.3 \%)$.

\section{f) Statistical analysis}

In order to relate the variables, the Chi-square test was utilized. $p$ values $<0.05$ (confidence interval $=95 \%$ ) were considered to be statistically significant. The experimental data were analysed using the software EPI Info (Version 6, USD Incorporated, Stone Mountain, GA, USA). 


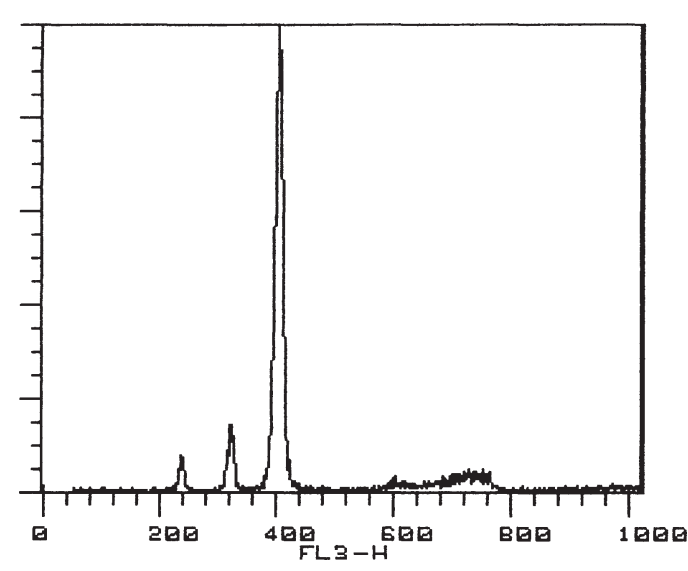

(a)

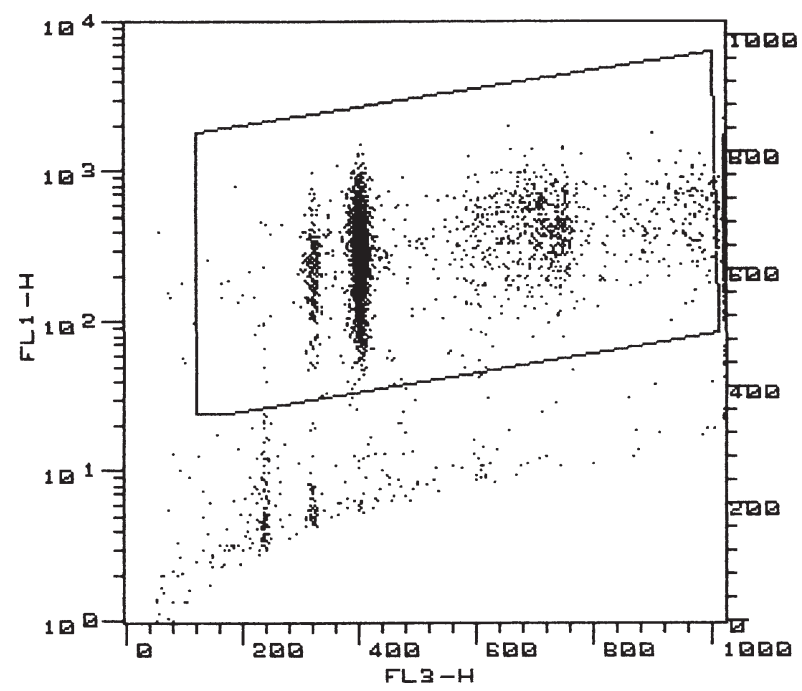

(c)

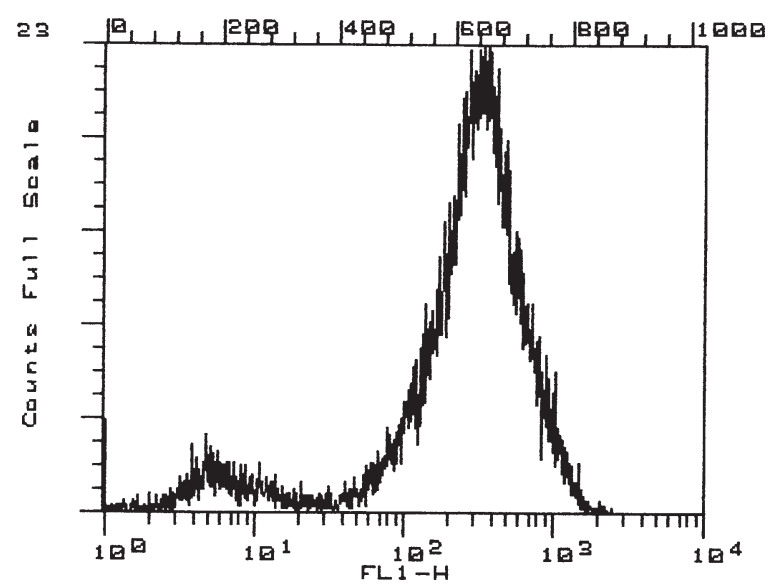

(b)

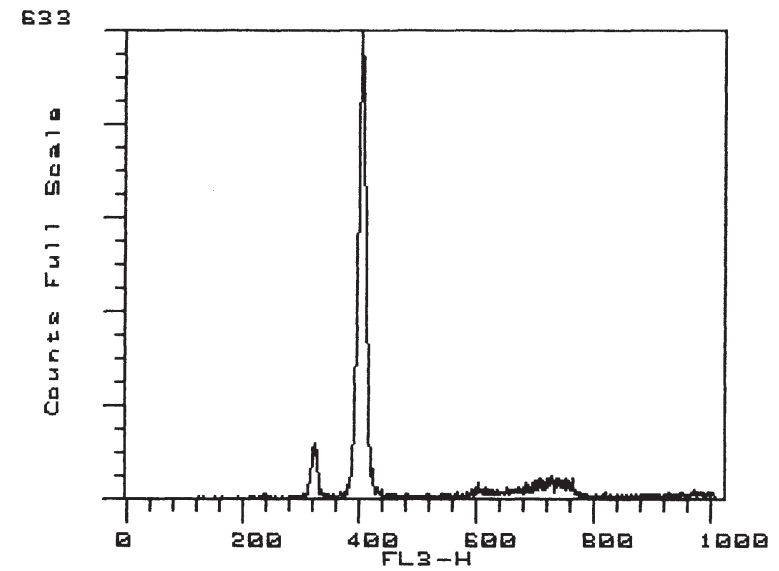

(d)

Fig. 5. (a) Ungated DNA histogram of a breast carcinoma with two abnormal DNA stemlines (DIs $=1.25$ and 1.70 ) and a population of cells with a normal DNA content; (b) histogram of green fluorescence (FL1-H) of cytocheratin labelled cells which shows two well separated peaks, relative to negative and positive immunolabelled cell populations; (c) dot plot with red fluorescence on the $X$ axis and green fluorescence on the $Y$ axis for dual labelled samples. CK-labelled cells were gated to generate a histogram (d) from the epithelial component only. Note the absence of a diploid peak, probably composed by inflammatory and stromal cells.

\section{Results}

Out of 136 cases, immunohistochemical evaluation of hormonal status showed that 66 cases (49\%) positive for both ER and PgR, 37 cases (27\%) positive for ER and negative for PgR, 33 cases (24\%) negative for both ER and PgR. P53 immunoreactivity was found in 41 cases (30\%) and c-erbB-2 overexpression in 26 cases (19\%). 


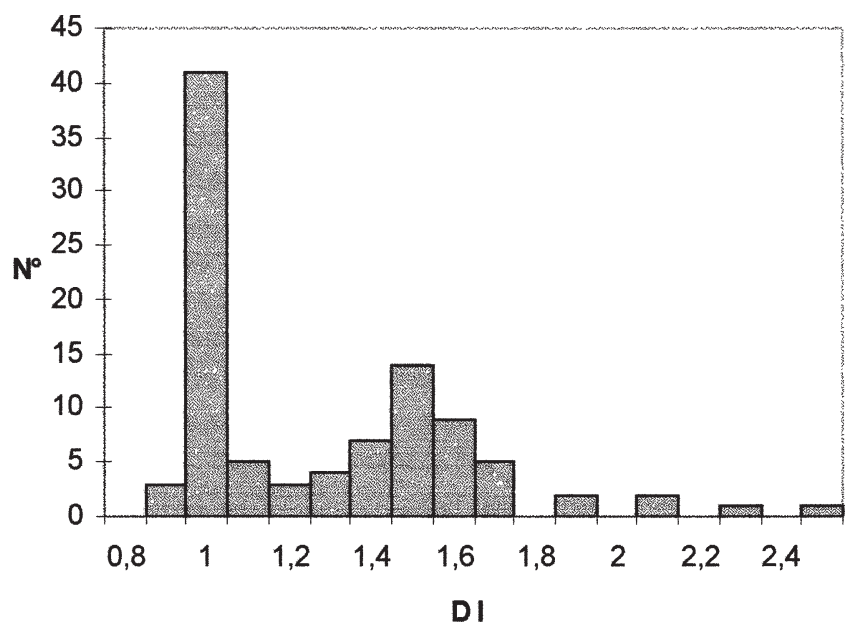

Fig. 6. Bar histogram showing DI distribution of the study population.

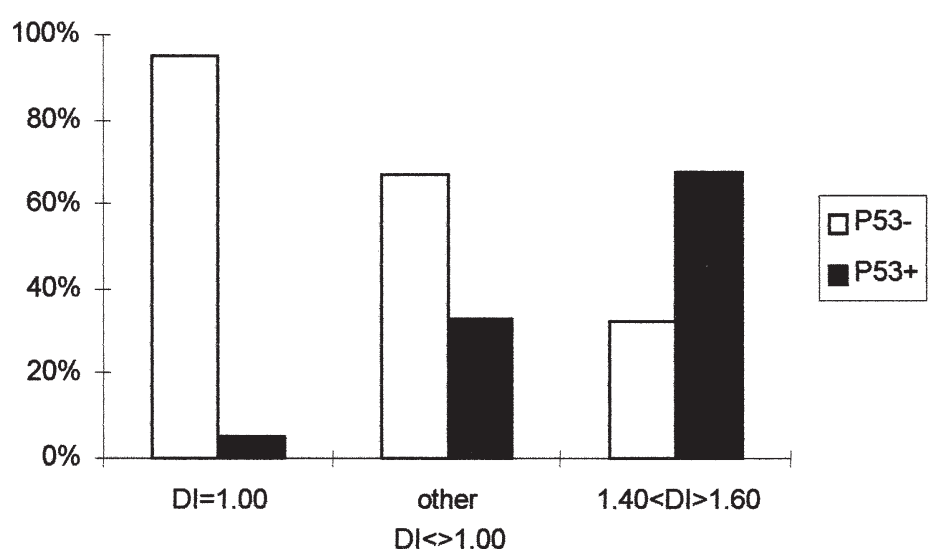

Fig. 7. Bar histogram showing the relation existing between DI classes and P53 immunohistochemical expression. Note the increasing \% of cases with high expression of P53 in the DNA near-triploid class (DI $=1.5 \pm 0.1$ ) in comparison with the other DI classes.

41 cases $(30 \%)$ were diploid and $95(70 \%)$ aneuploid. Distribution of DIs is shown in Fig. 6. SPF was evaluated by biparametric procedures on 106 cases (78\%). In 30 cases (22\%) SPF was not determined because the mathematical model fitting did not conform to the experimental data in the histograms.

We found strong correlations among DNA aneuploidy and high tumoral grade, absence of hormonal receptors, high proliferation as shown by high MIB-1 $(\geqslant 36 \%)$ and SPF values $(\geqslant 13.3 \%)$, and P53 positivity. DNA aneuploidy did not show significant correlations with pT, nodal status and c-erbB-2 overexpression (Table 2).

Subdividing the cases in DNA diploid, DNA near-triploid and other DNA aneuploids, the DNA near-triploid class showed significant correlations with presence of axillary metastases, high tumoral grade, absence of hormonal receptors, high proliferative activity expressed by MIB-1 $(\geqslant 36 \%)$ and SPF values $(\geqslant 13.3 \%)$, P53 positivity. DNA near-triploid aneuploidies did not correlate to the size of neoplastic lesions or to c-erbB-2 overexpression (Table 3). 
Table 2

Correlation of DNA ploidy by biparametric DNA/cytokeratin flow cytometry versus clinico-morphologic and biologic parameters $^{\mathrm{a}}$

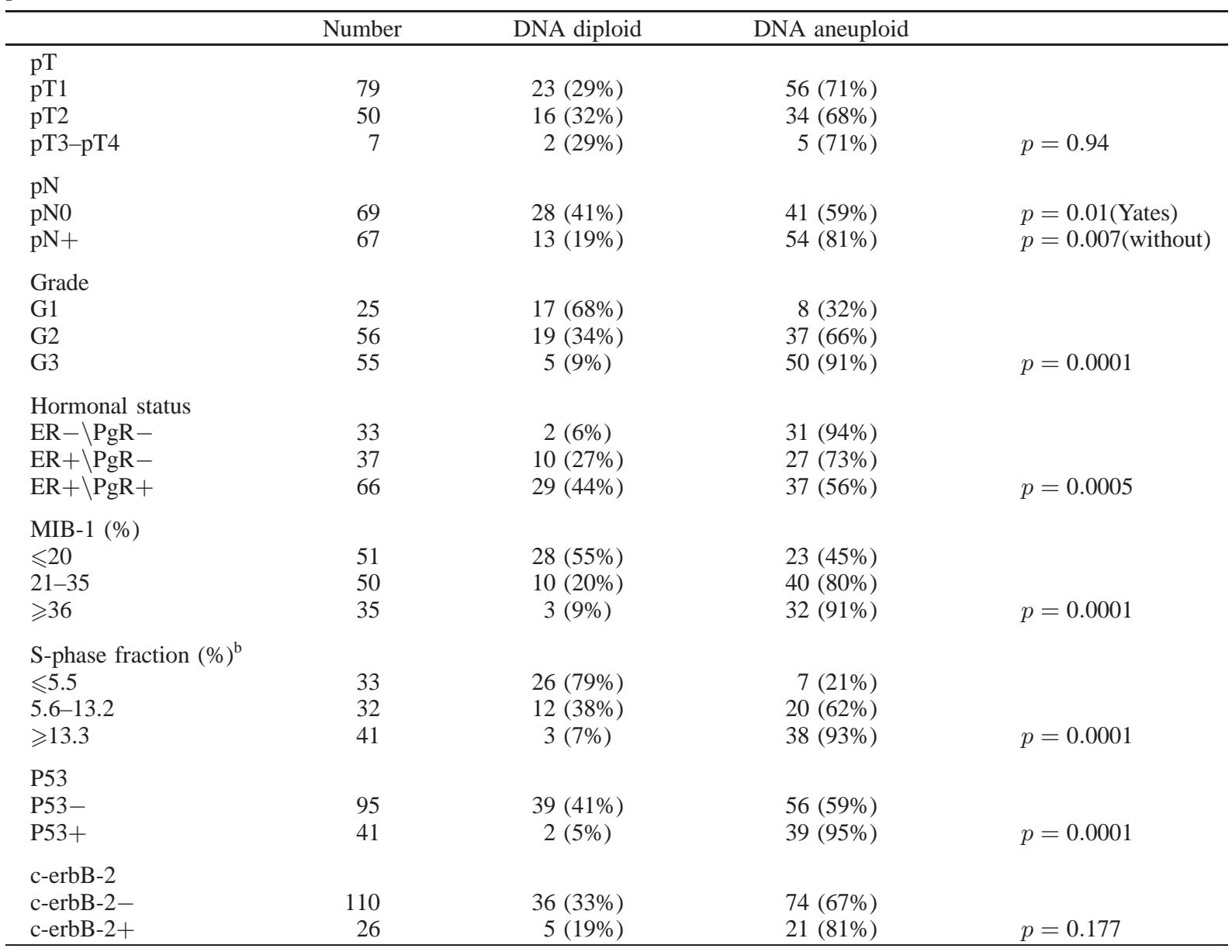

apT: assigned according to the TNM classification; grade: histological differentiation according to Bloom and Richardson; $\mathrm{N} 0, \mathrm{~N}+$ : absence or presence of axillary metastases; ER PgR $--/+-/++$ : negativity and positivity for hormonal receptors (cutoff for positivity $\geqslant 10 \%$ stained cells); MIB-1: percentile immunohistochemical expression of MIB-1 in neoplastic cells; SPF: fraction of cells in S-phase evaluated by flow cytometry; P53 - $/+$ immunohistochemical reactivity for P53 (cutoff for positivity $\geqslant 10 \%$ cells with nuclear staining); c-erbB-2 $-/+$ : immunoreactivity for c-erbB-2 (positivity only when membranous pattern was present).

${ }^{\mathrm{b}}$ It was not possible to determine S-phase values in 30 cases due to inadequate fitting of mathematical models.

Statistical significance for correlations with the above parameters was higher when subgrouping tumours in DNA diploids, DNA near-triploids and other DNA aneuploids. Specifically, statistical significance becomes markedly raised when DNA near-triploidy is related to P53 positivity (Fig. 7).

\section{Discussion}

In order to select patients with high risk of recurrence and neoplastic progression, many studies have focused on the characterization of biological features of neoplastic cells associated with aggressive 
Table 3

Correlation of DI groups to clinico-morphologic and biologic parameters. Data merging subdividing classes in diploid, triploid and other aneuploids ${ }^{\mathrm{a}}$

\begin{tabular}{|c|c|c|c|c|c|}
\hline & Number & DNA diploid & Other DIs $\neq 1$ & $\mathrm{DI}=1.5 \pm 0.1$ & \\
\hline \multicolumn{6}{|l|}{$\mathrm{pT}$} \\
\hline pT1 & 79 & $23(29 \%)$ & $45(57 \%)$ & $11(14 \%)$ & \\
\hline pT2 & 50 & $16(32 \%)$ & $24(48 \%)$ & $10(20 \%)$ & \\
\hline pT3-pT4 & 7 & $2(29 \%)$ & $4(57 \%)$ & $1(14 \%)$ & $p=0.86$ \\
\hline \multicolumn{6}{|l|}{ pN } \\
\hline pNO & 69 & $28(40 \%)$ & $33(48 \%)$ & $8(12 \%)$ & \\
\hline $\mathrm{pN}+$ & 67 & $13(19 \%)$ & $40(60 \%)$ & $14(21 \%)$ & $p=0.02$ \\
\hline \multicolumn{6}{|l|}{ Grade } \\
\hline G1 & 25 & $17(68 \%)$ & $7(28 \%)$ & $1(4 \%)$ & \\
\hline G2 & 56 & $19(34 \%)$ & $31(55 \%)$ & $6(11 \%)$ & \\
\hline G3 & 55 & $5(9 \%)$ & $35(64 \%)$ & $15(27 \%)$ & $p=0.0001$ \\
\hline \multicolumn{6}{|c|}{ Hormonal status } \\
\hline $\mathrm{ER}-\backslash \mathrm{PgR}-$ & 33 & $2(6 \%)$ & $18(55 \%)$ & $13(39 \%)$ & \\
\hline $\mathrm{ER}+\backslash \mathrm{PgR}-$ & 37 & $10(27 \%)$ & $22(59 \%)$ & $5(14 \%)$ & \\
\hline $\mathrm{ER}+\backslash \mathrm{PgR}+$ & 66 & $29(44 \%)$ & $33(50 \%)$ & $4(6 \%)$ & $p=0.0001$ \\
\hline \multicolumn{6}{|l|}{ MIB-1 (\%) } \\
\hline$\leqslant 20$ & 51 & $28(55 \%)$ & $19(37 \%)$ & $4(8 \%)$ & \\
\hline $21-35$ & 50 & $10(20 \%)$ & $33(66 \%)$ & $7(14 \%)$ & \\
\hline$\geqslant 36$ & 35 & $3(9 \%)$ & $21(60 \%)$ & $11(31 \%)$ & $p=0.0001$ \\
\hline \multicolumn{6}{|c|}{ S-phase fraction $(\%)^{\mathrm{b}}$} \\
\hline$\leqslant 5.5$ & 33 & $26(79 \%)$ & $5(15 \%)$ & $2(6 \%)$ & \\
\hline $5.6-13.2$ & 32 & $12(37 \%)$ & $15(47 \%)$ & $5(16 \%)$ & \\
\hline$\geqslant 13.3$ & 41 & $3(8 \%)$ & $26(63 \%)$ & $12(29 \%)$ & $p=0.0001$ \\
\hline \multicolumn{6}{|l|}{ P53 } \\
\hline P53- & 95 & $39(41 \%)$ & $49(52 \%)$ & $7(7 \%)$ & \\
\hline $\mathrm{P} 53+$ & 41 & $2(5 \%)$ & $24(58 \%)$ & $15(37 \%)$ & $p=0.0001$ \\
\hline \multicolumn{6}{|l|}{ c-erbB-2 } \\
\hline c-erbB-2- & 110 & $36(33 \%)$ & $57(52 \%)$ & $17(15 \%)$ & \\
\hline c-erbB-2+ & 26 & $5(19 \%)$ & $16(62 \%)$ & $5(19 \%)$ & $p=0.40$ \\
\hline
\end{tabular}

${ }^{a}$ DNA near-triploid: aneuploid tumours with DI $1.5 \pm 0.1$. See Table 2 for abbreviations.

${ }^{\mathrm{b}}$ It was not possible to determine S-phase values in 30 cases due to inadequate fitting of mathematical models.

growth, local and distant invasiveness and capability of spreading, surviving and flourishing at distant sites.

Prognostic factors in breast carcinoma include conventional clinico-pathologic parameters [42] as well as immunohistochemical evaluation of altered expression of tumour suppressor genes or oncogenes (P53, c-erbB-2) $[1,20,24,31,35,36,38,45]$ and proliferative activity $[2,6,9,15]$. These biological markers have an important role as independent prognostic parameters in relation to conventional clinico-pathologic characteristics (TNM, grade) which lead to the determination of tumour prognosis. The potential role of DNA content obtained by flow cytometry as a complement to these parameters in defining tumour prognosis has been discussed in several papers, but results are often conflicting. Some authors support FCM analysis of DNA ploidy as a strong prognostic factor while others do not find correlations to the above prognostic parameters [3,10,14,28]. The data from our study confirm the existence of a strong correlation among the presence of DNA content aneuploidy in neoplastic cells and other markers indicative of an unfavourable outcome, like poor differentiation (high tumoral 
Table 4

P53 immunoreactivity correlated to clinico-morphologic and biologic parameters ${ }^{\mathrm{a}}$

\begin{tabular}{lrrrr}
\hline & Number & P53- & P53+ & \\
\hline pT & & & & \\
pT1 & 79 & $55(70 \%)$ & $24(30 \%)$ & \\
pT2 & 50 & $38(76 \%)$ & $12(24 \%)$ & \\
pT3-pT4 & 7 & $2(29 \%)$ & $5(71 \%)$ & $p=0.04$ \\
pN & & & & \\
pN0 & 69 & $54(78 \%)$ & $15(22 \%)$ & \\
pN+ & 67 & $41(61 \%)$ & $26(39 \%)$ & $p=0.03$ \\
Grade & & & & \\
G1 & 25 & $24(96 \%)$ & $1(4 \%)$ & \\
G2 & 56 & $45(80 \%)$ & $11(20 \%)$ & \\
G3 & 55 & $26(47 \%)$ & $29(53 \%)$ & $p=0.0001$ \\
Hormonal status & & & & \\
ER- $\backslash$ PgR- & 33 & $15(45 \%)$ & $18(55 \%)$ & \\
ER+\PgR- & 37 & $27(73 \%)$ & $10(27 \%)$ & \\
ER+ $\$ PgR+ & 66 & $53(80 \%)$ & $13(20 \%)$ & $p=0.0002$ \\
MIB-1 (\%) & & & & \\
$\leqslant 20$ & 51 & $44(86 \%)$ & $7(14 \%)$ & \\
$21-35$ & 50 & $38(76 \%)$ & $12(24 \%)$ & \\
$\geqslant 36$ & 35 & $13(37 \%)$ & $22(63 \%)$ & $p=0.0001$ \\
S-phase fraction $(\%)^{\mathrm{b}}$ & & & & \\
$\leqslant 5.5$ & 33 & $30(91 \%)$ & $3(9 \%)$ & \\
$5.6-13.2$ & 32 & $27(84 \%)$ & $5(16 \%)$ & \\
$\geqslant 13.3$ & 41 & $20(49 \%)$ & $21(51 \%)$ & $p=0.0001$ \\
c-erbB-2 & & & & \\
c-erbB-2- & & $77(70 \%)$ & $33(30 \%)$ & \\
c-erbB-2+ & 26 & $18(69 \%)$ & $8(31 \%)$ & $p=0.94$ \\
\hline
\end{tabular}

${ }^{a}$ DNA near-triploid: aneuploid tumours with DI $1.5 \pm 0.1$. See Table 2 for abbreviations.

${ }^{\mathrm{b}}$ It was not possible to determine S-phase values in 30 cases due to inadequate fitting of mathematical models.

grade), high proliferative activity, absence of hormonal receptors and immunohistochemical reactivity for P53. Accumulation of P53 tumour suppressor gene protein, as revealed by immunohistochemistry, has been demonstrated to be an independent marker of poor prognosis in breast cancer [39], although some authors disagree on this point $[19,24]$. P53 was found to be associated to DNA aneuploidy $[1,20,29-31]$.

Observing DNA ploidy classes related to clinico-morphological and biological parameters, we found that tumours characterized by a near-triploid DI showed apparently more pronounced aggressive biological characteristics. In fact, this subgroup of neoplasms showed stronger statistical correlations with unfavourable prognostic parameters when compared to tumours with other DIs. In particular, statistical correlations with P53 were strongly enhanced.

A recent study on P53 immunoreactivity in colorectal cancer reported a strong association between P53 expression and flow cytometric DNA ploidy pattern. The authors demonstrated that P53 immunohistochemical expression was related with a higher frequency of aneuploid carcinomas with a DI $>1.20$ [23]. Another paper describing colorectal tumour progression noted the existence of a DNA aneuploid subclone with DNA Index $=1.50-1.80$ associated with an increased detection of genetic 
alterations involving P53 tumour suppressor gene in comparison to aneuploid carcinomas with DI $<$ $1.30[16,27]$.

Identification of a higher frequency of P53 immunoreactivity in tumours with DI values in the range of 1.40-1.60 may suggest the hypothesis that these cell subpopulations evolve in a distinct fashion in comparison to the other ploidy classes.

A recent paper discussing the origin of aneuploidy in bladder cancer hypothesizes a sequence of genetic changes leading to the creation of very aggressive aneuploid clones. Among these, triploid clones seem to exhibit a higher malignant potential in terms of deep invasiveness and capability to spread to distant sites [32].

Although these relations have been demonstrated in colorectal and bladder cancer, we can hypothesize a similar model for breast cancer on account of our results.

Our study, based on the flow cytometric analysis of the selected epithelial component of the tumour and on a rigorous application of the guidelines suggested by literature, makes an attempt to reach a high uniformity in sample processing as well as in interpretation of the results. The findings presented here may therefore be a starting-point for a better understanding of the complex biology and clinical behaviour of breast cancer.

\section{Acknowledgements}

We are grateful to Piera Paoletto and Giorgio Mattevi for their technical assistance. This study was supported by a grant of Lega Italiana per la Lotta Contro i Tumori - Serione di Trento, Italy.

\section{References}

[1] D.C. Allred, G.M. Clark, R. Elledge, S.A.W. Fukua, R.W. Brown, G.C. Chamness, C.K. Osborne and W.L. McGuire, Association of P53 protein expression with tumour cell proliferation rate and clinical outcome in node negative breast cancers, J. Natl. Cancer Inst. 85 (1993), 200-206.

[2] S. Anderson, J. Fuller and Y. Lin, Cellular proliferation in breast carcinoma as determined by MIB-1 immunostaining, Am. J. Clin. Pathol. 100 (1993), 324.

[3] A.D. Baildam, J. Zaloudik, A. Howell, D.M. Barnes, L. Turnbull, R. Swindell, M. Moore and R.A. Sellwood, DNA analysis by flow cytometry, response to endocrine treatment and prognosis in advanced carcinoma of the breast, $B r$. $J$. Cancer 55 (1987), 553-559.

[4] B. Baldetorp, P.O. Bendahl, M. Fernö, K. Alanen, U. Delle, U. Falkmer, B. Hansson-Aggesjö, T. Höckenström, A. Lindgren, L. Mossberg, S. Nordling, H. Sigurdsson, O. Stål and T. Visakorpi, Reproducibility in DNA flow cytometric analysis of breast cancer: comparison of 12 laboratories' results for 67 sample homogenates, Cytometry 22 (1995), 115-127.

[5] M. Barbareschi, E. Leonardi, F.A. Mauri, G. Serio and P. Dalla Palma, P53 and c-erbB-2 expression in breast carcinoma: an immunohistochemical study with correlations to receptor status, proliferation markers, and clinical stage in human breast carcinoma, Am. J. Clin. Pathol. 98 (1992), 408-418.

[6] N.J. Barnard, P.A. Hall, N.R. Lemoine and N. Kadar, Proliferative index in breast carcinoma determined in situ by Ki-67 immunostaining and its relationship to pathological and clinical variables, J. Pathol. 152 (1987), 287-295.

[7] E. Bergers, P.J. van Diest and J.P.A. Baak, Cell cycle analysis of 932 flow cytometric DNA histograms of fresh frozen breast carcinoma material, Cancer 77 (1996), 2258-2266.

[8] H.J.G. Bloom and W.W. Richardson, Histological grading and prognosis in breast cancer. A study of 1409 cases of which 359 have been followed for 15 years, Br. J. Cancer 11 (1957), 359-377.

[9] N. Bouzubar, K.J. Walker and K. Griffiths, Ki-67 immunostaining in primary breast cancer: pathological and clinical associations, Br. J. Cancer 59 (1989), 943-947.

[10] R.S. Camplejohn, C.M. Ash, C.E. Gillet, B. Raikundalia, D.M. Barnes, W.M. Gregory, M.A. Richards and R.R. Millis, The prognostic significance of DNA flow cytometry in breast cancer: results from 881 patients treated in a single centre, Br. J. Cancer 71 (1995), 140-145. 
[11] G. Cattoretti, M.H.G. Becker and G. Key, Monoclonal antibody against recombinant part of Ki67 antigen (MIB-1 and MIB-3) detect proliferating cells in microwave-processed formalin fixed paraffin embedded sections, J. Pathol. 168 (1992), 357-363.

[12] B. Chevallier, F. Heintzmann and V. Mosseri, Prognostic value of oestrogen and progesterone receptors in operable breast cancer. Results of a univariate and multivariate analysis, Cancer 62 (1988), 2517-2524.

[13] G.M. Clark, W.L. McGuire, C.A. Hubay, O.H. Pearson and J.S. Marshall, Progesterone receptor as a prognostic factor in stage II breast cancer, N. Engl. J. Med. 309 (1983), 1343-1347.

[14] B. Fisher, N. Gunduz, J. Costantino, E.R. Fisher, C. Redmond, E.P. Mamounas and R. Siderits, DNA flow cytometric analysis of primary operable breast cancer: relation of ploidy and S-phase fraction to outcome of patients in NSABP B-04, Cancer 68 (1991), 1465-1475.

[15] J. Gerdes, H. Lemke, H. Baisch, H.H. Wacker, U. Schwab and H. Stein, Cell cycle analysis of a cell proliferationassociated human nuclear antigen defined by the monoclonal antibody Ki-67, J. Immunol. 133 (1984), 1710-1715.

[16] W. Giaretti, A model of DNA aneuploidization and evolution in colorectal cancer, Lab. Invest. 71 (1994), 904-910.

[17] W.L. Gullik, The role of the epidermal growth factor receptor and c-erbB-2 protein in breast cancer, Int. J. Cancer 5 (1990), 55-61.

[18] D.W. Hedley, G.M. Clark, C.J. Cornelisse, D. Killander, T. Kute and D. Merkel, Consensus review of the clinical utility of DNA cytometry in carcinoma of the breast, Cytometry 14 (1993), 482-485.

[19] J. Hurlimann, Prognostic value of P53 protein expression in breast carcinomas, Path. Res. Pract. 189 (1993), 996-1003.

[20] J. Isola, T. Visakorpi, K. Holli and O.P. Kallionemi, Association of overexpression of tumour suppressor protein P53 with rapid cell proliferation and poor prognosis in node-negative breast cancer patients, J. Natl. Cancer Inst. 84 (1992), 1109-1114.

[21] A.A. Keshgegian and A. Cnaan, Proliferation markers in breast carcinoma, Am. J. Clin. Pathol. 104 (1995), $42-49$.

[22] R. Kimmig, H. Spelsberg, T. Kapsner, M. Untch and H. Hepp, Flow cytometric DNA analysis of breast cancer by two colour method using cytokeratin labeling for identification of tumour cells, Anal. Cell. Pathol. 7 (1994), 205-215.

[23] G. Lanza, I. Maestri, A. Dubini, R. Gafa', A. Santini, S. Ferretti and L. Cavazzini, P53 expression in colorectal cancer. Relation to tumour type, DNA ploidy pattern, and short term survival, Am. J. Clin. Pathol. 105 (1996), 604-612.

[24] G. MacGrogan, F. Bonichon, I. DeMascarel, M. Trojani, M. Durand, A. Avril and J.M. Coindre, Prognostic value of P53 in breast invasive ductal carcinoma: an immunohistochemical study on 942 cases, Breast Cancer Res. Treat. 36 (1995), 71-81.

[25] G. Mazzini and M. Danova, Citometria a flusso. Applicazioni cliniche dell'analisi del DNA in oncologia, in: I Manuali delle Scuole, Pavia, ed., 1994.

[26] W.L. McGuire, Steroid hormone receptors in breast cancer treatment strategy, Recent Prog. Horm. Res. 36 (1980), $135-156$.

[27] G.I. Meling, R.A. Lothe, A.L. Børresen, C. Graue, S. Hauge, O.P.F. Clausen and T.O. Rognum, The TP53 tumour suppressor gene in colorectal carcinomas. II. Relation to DNA ploidy pattern and clinico-pathological variables, $\mathrm{Br}$. J. Cancer 67 (1993), 93-98.

[28] S.M. O'Reilly, R.S. Camplejohn, D.M. Barnes, R.R. Millis, D. Allen, R.D. Rubens and M.A. Richards, DNA index, S-phase fraction, histological grade and prognosis in breast cancer, Br. J. Cancer 61 (1990), 671-674.

[29] A. Pich, E. Margaria, L. Chiusa, R. Ponti and M. Geuna, DNA ploidy and P53 expression correlated with survival and cell proliferative activity in male breast cancer, Hum. Pathol. 27 (1996), 676-682.

[30] G.P. Rosanelli, P. Steindorf, G.H. Wirnsberger, M. Klimpflinger, M. Ratschek, P. Puerstner, H. Auner and A. Berthold, Mutant P53 expression and DNA analysis in human breast cancer; comparison with conventional clinico-pathologic parameters, Anticancer Res. 15 (1995), 581-586.

[31] H. Schimmelpenning, E.T. Eriksson, A. Zetterberger and G.U. Auer, Association of immunohistochemical P53 tumour suppressor gene protein overexpression with prognosis in highly proliferative human mammary adenocarcinomas, World J. Surg. 18 (1994), 827-833.

[32] S.E. Shackney, G. Berg, S.R. Simon, J. Cohen, S. Amina, W. Pommersheim, R. Yakulis, S. Wang, M. Uhl, C.A. Smith, A.A. Pollice and R.J. Hartsock, Origins and clinical implications of aneuploidy in early bladder cancer, Cytometry 22 (1995), 307-316.

[33] T.V. Shankey, P.S. Rabinovitch, B. Bagwell, K.D. Bauer, R.E. Duque, D.W. Hedley, B.H. Mayall and L. Wheeless, Guidelines for implementation of clinical DNA cytometry, Cytometry 14 (1993), 472-477.

[34] S.R. Shi, M.E. Key and K.L. Kaira, Antigen retrieval in formalin-fixed, paraffin-embedded tissues: an enhancement method for immunohistochemical staining based on microwave oven heating of tissue sections, J. Histochem. Cytochem. 39 (1991), 741-748.

[35] T.P. Singleton and J.G. Strickler, Clinical and pathological significance of the c-erbB-2 (HER-2/neu) oncogene, Pathol. Аnпи. 27 (1992), 165-190.

[36] D.J. Slamon, G.M. Clark, S.G. Wong, W.J. Levin, A. Ullrich and W.L. McGuire, Human breast cancer: correlation of relapse and survival with amplification of the HER-2/neu oncogene, Science 235 (1987), 177-182. 
[37] B. Spiessl, TNM-Atlas: An Illustrated Guide to the TNM/pTNM-Classification of Malignant Tumours, Springer, New York, 1989, pp. 174-183.

[38] M. Stenmark-Askmalm, O. Stal, K. Olsen and B. Nordenskjold, P53 as a prognostic factor in stage I breast cancer, Br. J. Cancer 72 (1995), 715-719.

[39] A.D. Thor, D.H. Moore II, S.M. Edgerton, E.S. Kawasaki, E. Reihsaus, H.T. Lynch, J.N. Marcus, L. Schwartz, L.C. Chen, B.H. Mayall and H.S. Smith, Accumulation of P53 tumour suppressor gene protein: an independent marker of prognosis in breast cancer, J. Natl. Cancer Inst. 84 (1992), 845-855.

[40] S.M. Veronese, M. Barbareschi, L. Morelli, A. Aldovini, F.A. Mauri, O. Caffo, M. Gambacorta and P. Dalla Palma, Predictive value of ER1D5 antibody immunostaining in breast cancer, Appl. Immunohistochem. 3 (1995), 85-90.

[41] D.W. Visscher, P. Sochacki, S. Ottosen, S. Wykes and J.D. Crissman, Assessment and significance of diploid-range epithelial populations in DNA aneuploid breast carcinomas using multi-parametric flow cytometry, Anal. Cell. Pathol. 8 (1995), 267-277.

[42] D.W. Visscher, R.J. Zarbo, K.A. Greenwald and J.D. Crissman, Prognostic significance of morphological parameters and flow cytometric DNA analysis in carcinoma of the breast, Pathol. Annu. (Part I) 25 (1990), 171-210.

[43] D.W. Visscher, R.J. Zarbo, G. Jacobsen, A. Kambouris, G. Talpos, W. Sakr and J.D. Crissman, Multiparametric deoxyribonucleic acid and cell cycle analysis of breast carcinomas by flow cytometry, Lab. Invest. 62 (1990), 370-378.

[44] R.P. Wersto, R.L. Liblit and L.G. Koss, Solid tumours: a review of the interpretation of DNA histograms, Hum. Pathol. 22 (1991), 1085-1098.

[45] C. Wiltschke, I. Kindas-Muegge, A. Steininger, A. Reiner, G. Reiner and P.N. Preis, Coexpression of Her-2/Neu and P53 is associated with a shorter disease-free survival in node-positive breast cancer patients, J. Cancer Res. Clin. Oncol. 120 (1994), 737-742.

[46] S. Wingren, O. Stål, J. Carstensen, X.F. Sun and B. Nordenskjöld, S-phase determination immunoselected cytokeratincontaining breast cancer cells improves the prediction of recurrence, Breast Cancer Res. Treat. 29 (1993), 179-187.

[47] S. Wingren, O. Stål and B. Nordenskjöld, Flow cytometric analysis of S-phase fraction in breast carcinomas using gating on cells containing cytokeratin, Br. J. Cancer 69 (1994), 546-549.

[48] S. Wingren, O. Stål, S. Sullivan, A. Brisfors and B. Nordenskjöld, S-phase fraction after gating on epithelial cells predicts recurrence in node-negative breast cancer, Int. J. Cancer 59 (1994), 7-10.

[49] R.J. Zarbo, R.D. Brown, M.D. Linden, F.X. Torres, R.E. Nakhleh and D.S. Schultz, Rapid (one-shot) staining method for two-color multiparametric DNA flow cytometric analysis of carcinomas using staining for cytokeratin and leukocyte common antigen, Am. J. Clin. Pathol. 101 (1994), 638-642.

[50] R.J. Zarbo, D.W. Visscher and J.D. Crissman, Two-color multiparametric method for flow cytometric DNA analysis of carcinomas using staining for cytokeratin and leukocyte-common antigen, Anal. Quant. Cytol. Histol. 11 (1989), $391-402$.

[51] I. Zbieranowski, C. Demianiuk, V. Bell, W.A. Knape and D. Murray, Detection of false DNA aneuploidy and false DNA multiploidy in flow cytometric DNA analysis, Anal. Cell. Pathol. 5 (1993), 69-84. 


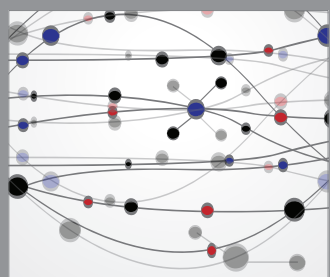

The Scientific World Journal
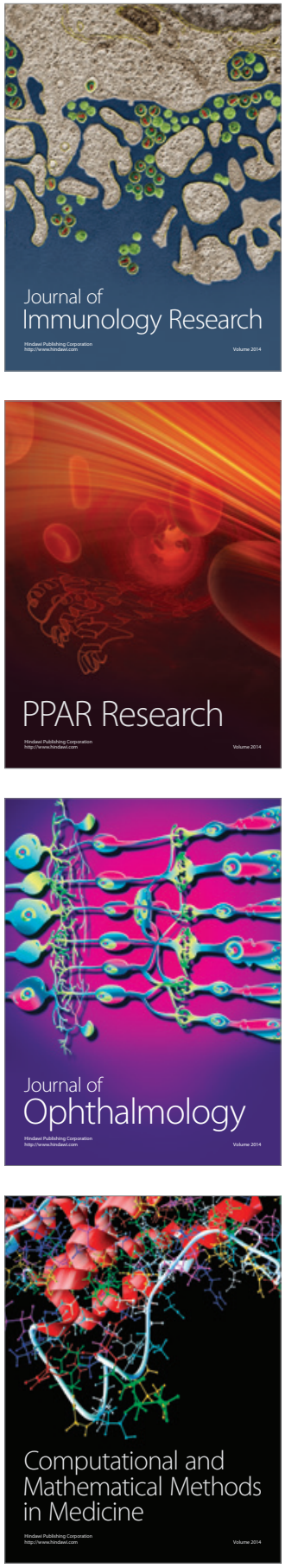

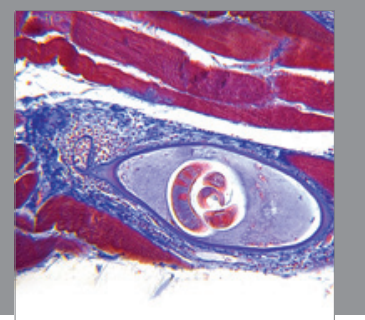

Gastroenterology

Research and Practice
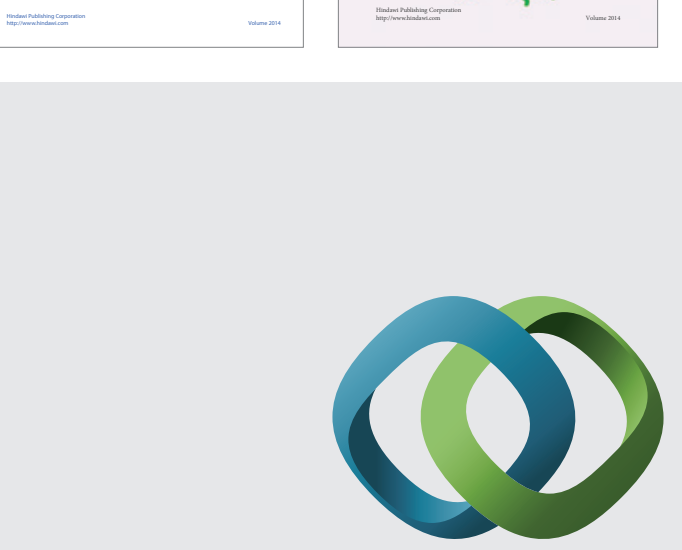

\section{Hindawi}

Submit your manuscripts at

http://www.hindawi.com
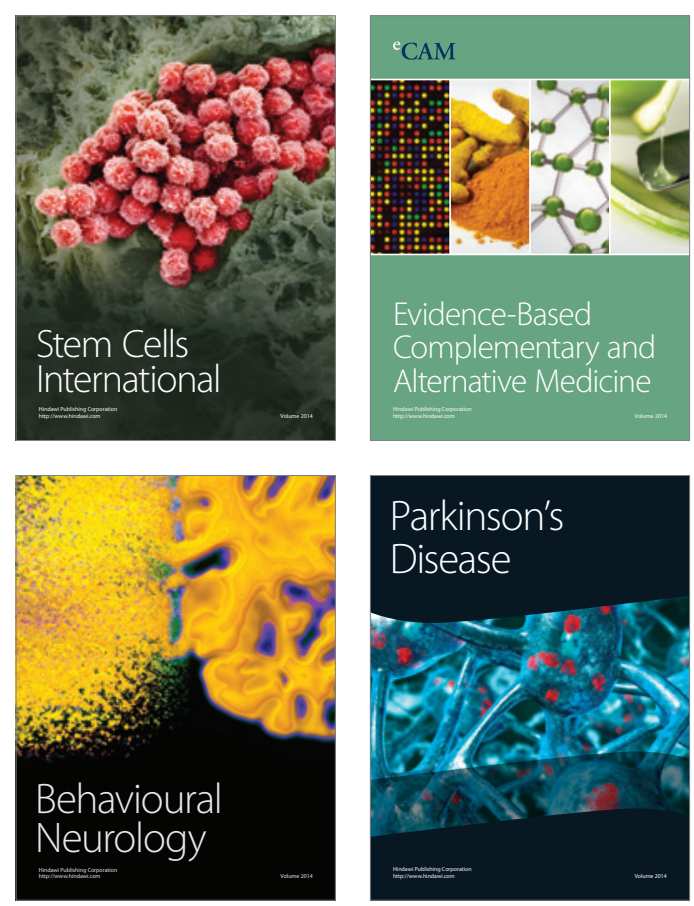

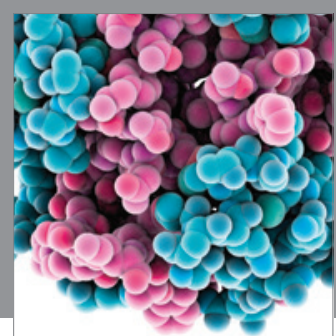

Journal of
Diabetes Research

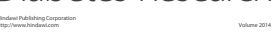

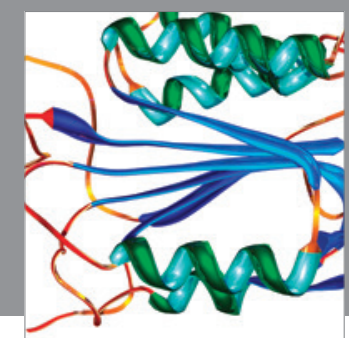

Disease Markers
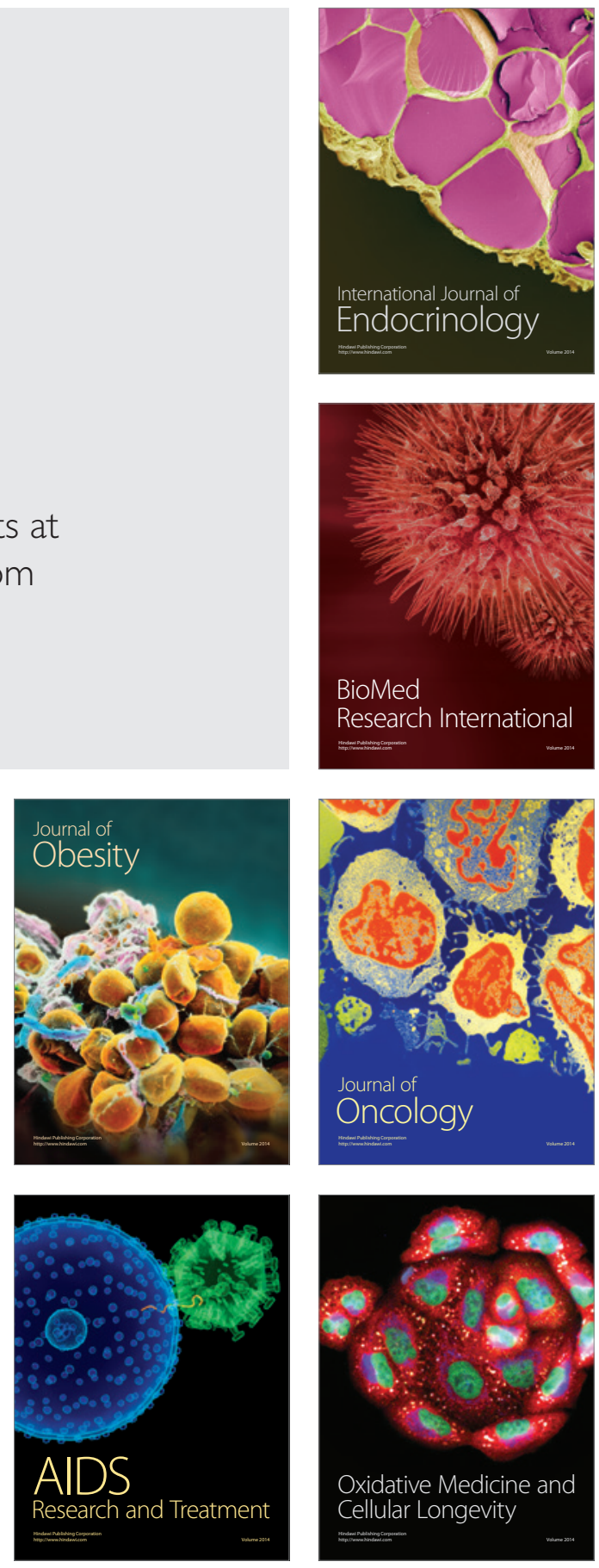